\title{
ASTROMETRIC CCD OBSERVATIONS OF SELECTED WDS MULTIPLE STAR SYSTEMS
}

\author{
N.V. Maigurova, Yu.I. Protsyuk, L.E. Bondarchuk \\ Research Institute "Mykolaiv Astronomical Observatory", Mykolaiv, Ukraine \\ nadija@nao.nikolaev.ua,yuri@nao.nikolaev.ua
}

\begin{abstract}
Main objective of the study is getting information about multiple and double stars that allow us to determine whether this pair is physically link system. Physically bounded star systems are source of unique information such as the ratio of the periods of pairs in one system, the relative orientation of the orbital planes, the distribution of components by mass which is extremely important for determining the parameters of star formation models and for testing stellar models evolution. The results of selected multiple star systems CCD observations, which were carried out at the KT-50 telescope of the Research Institute "Mykolaiv Astronomical Observatory" during the 2016-2018 years are presented. The Washington catalog of double stars (WDS) was used for observational list. There were presented detailed study of 14 multiple star systems. Astrometric reductions of the CCD frames with multiple system components at the current epoch were performed using "Astrometrica" software with Gaia DR2 reference catalog. The combination of the $\mathrm{CCD}$ received data with other Strasbourg base catalogs allowed to determine the new values of stars proper motions. Parameters of mutual component configuration (position angle and separation) were also measured for the components of the multiple star systems using REDUC software. The measures standard errors were $0.05^{\prime \prime}$ for separations and $0.2^{\circ}$ for position angles. Combination ground based original observations with accurate astrometric catalogs available due to Strasbourg astronomical Data Center allowed us obtain new knowledge about investigated objects.
\end{abstract}

Keywords: Double and multiple stars, binary stars, CCD observations, astrometric positions, common proper motions

АБСТРАКТ. Основною метою дослідження $\epsilon$ отримання інформації про системи кратних та подвійних зірок, які дозволяють нам визначити, чи є вони фізично-зв'язаною системою. Кратні та подвійні системи зірок є джерелом унікальної інформації, такої як співвідношення періодів пар в одній системі, відносна орієнтація орбітальних площин, розподіл компонентів за масою та інш., що надзвичайно важливо для визначення параметрів моделей утворення та еволюції зірок. Представлені результати ПЗ3 спостережень вибраних кратних зоряних систем, що проводилися на телескопі КТ-50 НДІ "Миколаївська астрономічна обсерваторія" протягом
2016-2018 років. У якості вхідного списку для спостережень використовувався Вашингтонський каталог подвійних зірок (WDS). Дана робота представляє детальне дослідження 14 кратних зоряних систем. Астрометричні редукції ПЗ3 - кадрів на момент спостережень, що містять компоненти досліджуваних кратних систем, були виконані за допомогою програми "Astrometrica" у системі опорного каталогу GAIA DR2. Комбінація положень, що отримано 3 наших спостережень та положень 3 інших каталогів із Страсбурзької бази даних дозволила визначити нові значення власних рухів компонентів цих зоряних систем. Параметри взаємної конфігурації компонентів (позиційний кут та кутове розділення) також були виміряні для компонентів вибраних зоряних систем за допомогою програми REDUC. Стандартні похибки вимірювань склали $0.05 "$ для кутового розділення та $0.2^{\circ}$ для позиційного кута. Комбінація даних наших астрометричних спостережень 3 даними високоточних астрометричних каталогів, що $\epsilon$ доступними через Страсбурзький астрономічний центр даних, дозволили нам отримати нові знання про досліджувані об'єкти.

Ключові слова: подвійні та кратні зоряні системи, фізично зв'язані подвійні зорі, ПЗ3-спостереження, астрометричні положення, власні рухи.

\section{Introduction}

The Washington Double Star Catalog (WDS) (Mason et al., 2001) lists 142,785 (on the summer 2018) of resolved stellar systems with two and more components. Number of WDS systems with more than 3 components is $59 \%$. Hierarchical systems with known orbits are of special interest objects. Compared to binaries, hierarchical multiples with three or more components contain additional information such as period ratios, mass ratios, and relative orbit orientation. Study (Tokovinin et al., 2014) has shown that $46 \%$ of solar-type stars (F-G spectral type) in the vicinity of $67 \mathrm{pc}$ from Sun are nonsingle and the ratio of stellar systems with a multiplicity of 1: 2:3:4:5 is 54:33: $8: 4: 1$. However, a substantial fraction of the WDS entries are random combinations of background stars. Despite to almost any bright star has faint optical components in the WDS typically their secondary components are faint and often located in crowded regions of the sky. Proper motions are absent for 
$32 \%$ secondary component in WDS catalog, which makes it impossible to understand the true nature of these objects. The appearance Gaia DR2 catalog, that contains highly accurate positions, parallaxes, and proper-motions for more than 1 billion sources brighter than magnitude 20.7 in the white-light photometric $\mathrm{G}$ band, significantly will improve the situation on this issue. At the same time, ground-based observations do not lose their value due to the specifics of these objects and space observations.

\section{Observations and Reductions}

The regular observations of binary and multiple stars at RI «MAO» have been carried out since 2013 at two telescopes: Axial Meridian Circle and KT-50 of Mobitel complex (Shulga A.V. et al., 2012; Bodryagin et al, 2015; Bodryagin et al, 2016; Bodryagin et al, 2017). For this study we used observations that obtained at KT-50 telescope (Mobitel complex) during 2016 -2018. 14 multiple systems were checked from WDS catalog. Some information about these systems is presented in Tab.1. The Tab.1 are given stellar magnitudes of primary component (Mag1) and magnitudes for faintest component (Mag 2), information about proper motions availability for primary $(\mathrm{Pm} 1)$ and secondary $(\mathrm{Pm} 2)$. If at least one of system component has no proper motion there is "-" in column Pm2.

Table 1: Selected WDS systems

\begin{tabular}{|c|c|r|c|c|c|}
\hline WDS & N & Mag1 & $\begin{array}{c}\text { Mag2 } \\
\text { (min) }\end{array}$ & Pm1 & Pm2 \\
\hline $\mathbf{0 9 5 8 7 + 1 0 5 8}$ & 3 & 7.5 & 11.7 & + & + \\
\hline $\mathbf{1 0 0 9 7 + 0 3 1 0}$ & 3 & 8.5 & 12.0 & + & + \\
\hline $\mathbf{1 1 5 3 7 + 7 3 4 5}$ & 4 & 7.2 & 16.5 & + & - \\
\hline $\mathbf{1 2 0 5 6 + 6 8 4 8}$ & 6 & 7.5 & 12.7 & + & - \\
\hline $\mathbf{1 2 0 8 2 + 6 0 3 0}$ & 4 & 10.5 & 15.2 & + & + \\
\hline $\mathbf{1 2 1 8 7 + 1 1 4 8}$ & 3 & 9.5 & 11.8 & + & + \\
\hline $\mathbf{1 2 3 3 9 + 2 6 0 3}$ & 3 & 11.5 & 14.1 & + & + \\
\hline $\mathbf{1 2 3 9 6 + 1 9 5 6}$ & 3 & 8.5 & 15.2 & + & - \\
\hline $\mathbf{1 2 4 1 8 + 0 9 5 3}$ & 5 & 7.0 & 14.4 & + & - \\
\hline $\mathbf{1 2 4 2 9 - 0 2 1 5}$ & 3 & 9.2 & 13.8 & + & + \\
\hline $\mathbf{1 2 4 9 7 + 0 1 1 1}$ & 4 & 8.2 & 14.0 & + & - \\
\hline $\mathbf{1 2 5 2 5 + 0 7 1 2}$ & 4 & 9.6 & 15.1 & + & - \\
\hline $\mathbf{1 2 5 5 0 + 5 8 1 0}$ & 3 & 8.6 & 9.8 & + & + \\
\hline $\mathbf{1 7 4 7 9 + 3 4 1 7}$ & 4 & 6.6 & 13.3 & + & - \\
\hline
\end{tabular}

\subsection{Astrometric Reductions}

The CCD observations of fields with selected WDS systems were obtained in drift scan mode at near $\mathrm{R}$ photometric band (OC-14 filter) and at V band (Johnson system) starting from 2018. The numbers of the images for each objects is given in Tab.2. The astrometric reductions of observations were carried out by the package "Astrometrica" (http://www.astrometrica.at), version 4.11.1.442. Reference catalogs Gaia DR2 (Gaia Collaboration, 2018) and UCAC4 (Zacharias N. et al., 2013) were used for calculations of equatorial coordinates of stars in the fields. The comparison of mutual distributions of residuals differences $(\mathrm{O}-\mathrm{C})$, with different catalogs are shown in Fig. 1. The differences (OC) are used in mean $\mathrm{O}$ - positions obtained from observations, $\mathrm{C}$ - catalog positions.

As can be seen from Fig.1, the usage of GAIA DR2 catalog as reference allows improving accuracy of obtained positions up to $20 \%$. Mean errors in both right ascension and declination for a single observation depends from stellar magnitude and are in range (20 -30) mas for $(12-15)^{\mathrm{mag}}$, and up to $100 \mathrm{mas}$ for $17^{\mathrm{mag}}$.
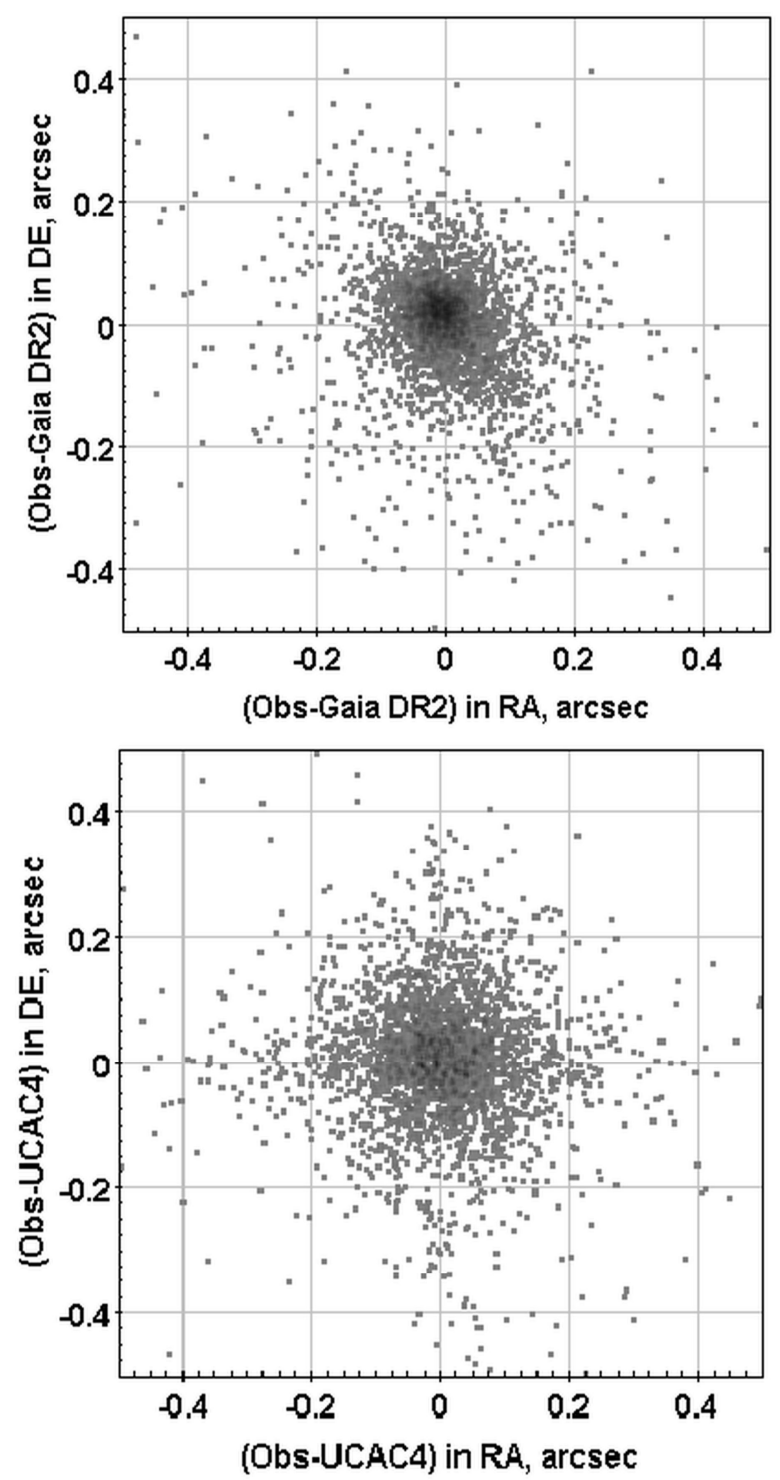

Figure1: Distributions of residuals differences $(\mathrm{O}-\mathrm{C})$ in right ascension and declination (up - GAIA DR2 reference catalog, down - UCAC4 reference catalog.

\subsection{Measurements}

The measurements of doubles were made with REDUC software (http://www.astrosurf.com/hfosaf/reduc).

To determine frame orientation, we used previously obtained exact values of orientation angle and image inclination regarding the celestial equator from astrometric reductions. Position angles, separations, and their standard deviations were measured for each component of selected WDS systems. A more detailed 
description of the processing procedure is given in (Bodryagin et al, 2016). The results of measurements of A, B mutual configuration (with exception of WDS $11537+7345$ ) are shown in Tab.2. (For WDS $11537+7345$ $\mathrm{A}$ and $\mathrm{B}$ component form a spectroscopic binary system and has separation only 0.5 ".)

Table 2: Result of measurements of $\mathrm{AB}$ component for selected WDS systems

\begin{tabular}{|c|r|r|r|c|c|}
\hline WDS & PA,deg & $\begin{array}{c}\text { RMS } \\
\text { PA }\end{array}$ & Sep & RMS & N \\
\hline $09587+1058$ & 347.73 & 0.09 & 49.08 & 0.11 & 16 \\
\hline $10097+0310$ & 52.57 & 0.06 & 89.62 & 0.07 & 16 \\
\hline $11537+7345^{*}$ & 59.45 & 0.17 & 36.90 & 0.13 & 11 \\
\hline $12056+6848$ & 166.80 & 0.50 & 10.20 & 0.11 & 10 \\
\hline $12082+6030$ & 23.73 & 0.01 & 30.80 & 0.04 & 5 \\
\hline $12187+1148$ & 239.89 & 0.36 & 9.53 & 0.08 & 10 \\
\hline $12339+2603$ & 337.65 & 0.36 & 15.84 & 0.12 & 10 \\
\hline $12396+1956$ & 148.22 & 0.07 & 413.99 & 0.11 & 5 \\
\hline $12418+0953$ & 101.83 & 0.04 & 112.75 & 0.03 & 5 \\
\hline $12429-0215$ & 92.42 & 0.11 & 53.77 & 0.11 & 10 \\
\hline $12497+0111$ & 336.71 & 0.03 & 197.87 & 0.08 & 12 \\
\hline $12525+0712$ & 87.39 & 0.20 & 32.66 & 0.06 & 10 \\
\hline $12550+5810$ & 274.19 & 0.36 & 18.65 & 0.07 & 10 \\
\hline $17479+3417$ & 348.44 & 0.20 & 30.34 & 0.08 & 4 \\
\hline
\end{tabular}

*Measurements for A, D component

Mean RMS errors of the measurements for all pair components in the selected systems were $0.18^{\circ}$ in positional angle and $0.1^{\prime \prime}$ in separation.

\section{Results}

The astrometric positions on observational epoch of all measurable components of the selected WDS systems were obtained from astrometric reductions. The results of cross-identification of the resulting array of star positions with the main modern catalogs, which can be an additional source of information about the components of selected systems, are presented in Tab. 3 .

Table 3: Results of Cross-ID Mobitel KT-50 data with CDS data catalogs

\begin{tabular}{|l|c|c|}
\hline \multicolumn{1}{|c|}{ Catalog } & N & Mean Epoch \\
\hline Mobitel KT50 & 45 & 2017.19 \\
\hline Gaia DR2 & 44 & 2015.50 \\
\hline GSS 2.3 & 43 & 1996.20 \\
\hline Pan-STARRS DR1 & 45 & 2010.17 \\
\hline SDSS DR12 & 41 & 2003.86 \\
\hline UCAC5 & 44 & 2001.77 \\
\hline AC2000 & 33 & 1907.00 \\
\hline
\end{tabular}

The cross-ID procedure was made with using Vizier service by TOPCAT software (Taylor M. B., 2005). The usage of original positions on catalog observation epoch can find out stars with common proper motions and compare the shot-term measured Gaia DR2 proper motions with the long-term averaged. It should be noted the lock of the components in AC2000 catalog makes it impossible to obtain reliable differences with Gaia data.

Below the more detailed study results for 2 WDS systems are presented with using positional information from different CDS catalogs and data about distances from Bailer-Jones et.al (2018).

The table 4 provides estimates and confidence intervals of distances for the components of WDS $12056+6848$ and WDS $12082+6030$.

Table 4: Distances for selected components from BailerJones et.al (2018)

\begin{tabular}{|c|r|c|}
\hline WDS & D, pc & \multicolumn{1}{|c|}{$\Delta, \mathbf{p c}$} \\
\hline $12056+6848$ & & \\
\hline A & $\mathbf{2 1 7 . 8}$ & $\mathbf{2 1 5 . 8 - 2 1 9 . 8}$ \\
\hline B & $\mathbf{2 0 9 . 0}$ & $\mathbf{2 0 7 . 9 - 2 1 0 . 0}$ \\
\hline C & 476.3 & $471.1-484.5$ \\
\hline D & 426.2 & $421.2-431.2$ \\
\hline E & 355.4 & $350.6-360.3$ \\
\hline F & 469.6 & $464.1-475.3$ \\
\hline $12082+6030$ & & \\
\hline A & 789.7 & $773.1-789.7$ \\
\hline B & $\mathbf{2 2 8 . 3}$ & $\mathbf{2 2 6 . 7 - 2 3 0 . 0}$ \\
\hline C & $\mathbf{2 3 2 . 9}$ & $\mathbf{2 3 1 . 3 - 2 3 4 . 5}$ \\
\hline D & 1064.1 & $1033.2-1096.8$ \\
\hline \multicolumn{2}{|l}{}
\end{tabular}

\subsection{WDS $12056+6848$}

This WDS system from the list of the objects studied has the largest (6) number of entries in the WDS catalog. «Notes» column information says that the A, B components form non-physical pair, as $A$ and $E$ components have physical link. KT-50 positions were added to the positions checked from different catalogues and long-term proper motions were calculated from linear interpolation function. As can be seen from Fig.2 only A, B components have common proper motions and can be physical pair. These data are in good agreement with Gaia DR2 proper motions and distances from Bailer-Jones et.al (2018).

\subsection{WDS $12082+6030$}

There are 4 entries for this system in WDS catalog and in «Notes» column contains information that these pairs are non-physical. The Tab.4 distance data allow us to suggest that this is not true and the components $\mathrm{B}, \mathrm{C}$ form a binary system. The positions of the $\mathrm{B}, \mathrm{C}$ components obtained from KT-50 and CDS catalogs at different epoch are presented in Fig.3. The proper motions in right ascension and declination that calculated from these data are: $-3 /-14$ mas/year for $B$ and $-2 /-17$ mas/year for $C$ component. These values are in good agreement with GAIA DR2 (-2/-14mas/year and -1/-14mas/year) proper motions. All of the above point that component $\mathrm{B}$ and $\mathrm{C}$ likely physical pair. 

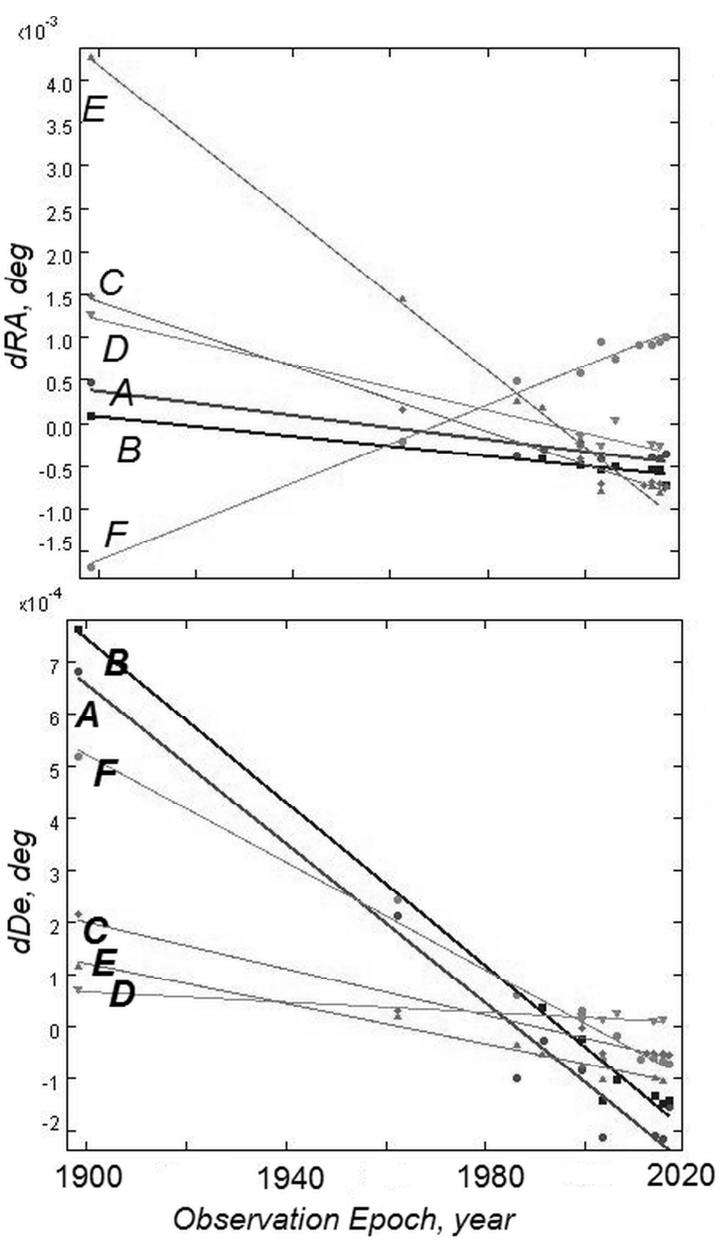

Figure 2: Component positions of the WDS12056+6848 on different catalog epochs, up - right ascension, down declination.

\section{Conclusion}

Positional data obtained for physically connected components are valuable information for the catalog of orbital elements (Orb6) of binary and multiple stars. New observations of the components of multiple systems on the KT-50 telescope of the Mobitel RI "MAO" complex are obtained. Astrometric reductions and measurements of the parameters of the mutual configuration of the selected WDS multiple systems are performed. Combination new original observations with accurate catalogs available at Strasbourg astronomical Data Center allows not only to obtain new knowledge about investigated objects but also to estimate the accuracy of so-called "instantaneous" parallaxes and proper motions from Gaia catalog.

Observation data and analysis of the results will be sent to the coordinators of the WDS catalog database. We are also planning to continue use resources of MAO to future analysis and refinement of the results.

Acknowledgements. The authors are grateful to colleagues from RI "MAO" who have taken part in observations of WDS stars: M. Kulichenko, M. Kaliuzhnyi, V. Kryuchkovskiy, D. Bodryagin, F. Bushuev, A. Pomazan.
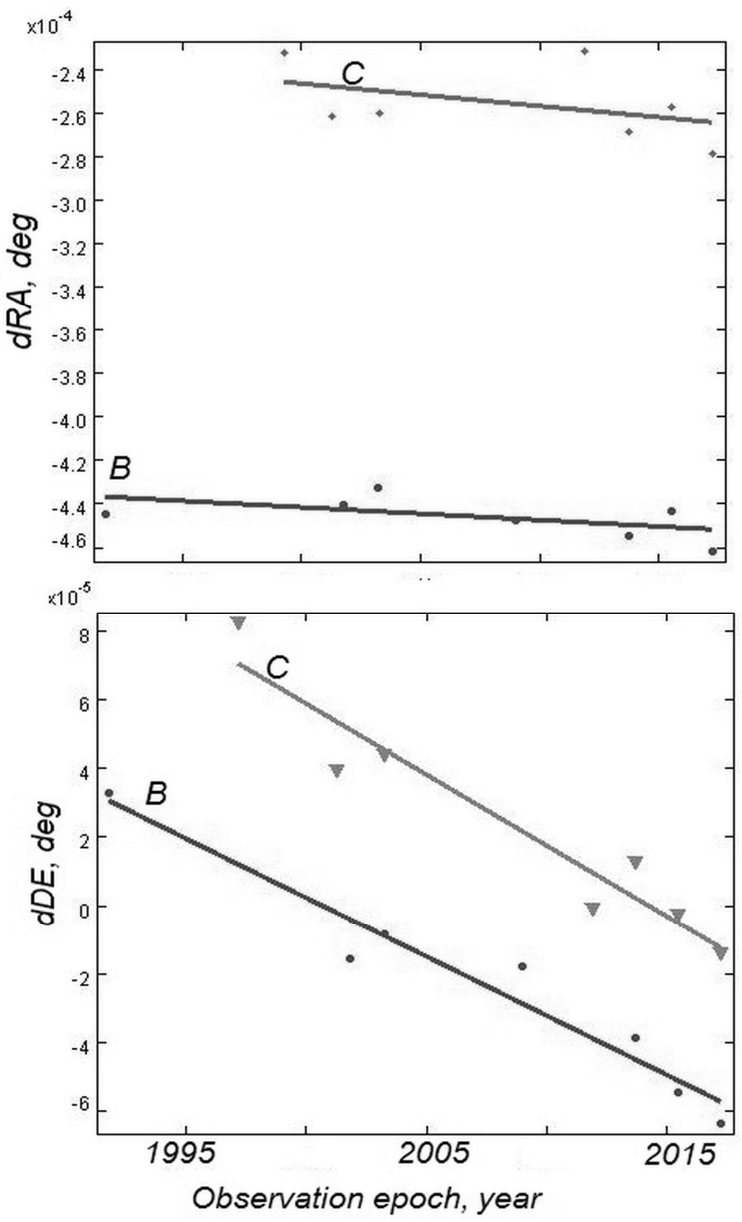

Figure 3: Positions of the B, C WDS12082+6030 component on different catalog epochs, up - right ascension, down - declination.

\section{References}

Astromerica, [online]. Available at:

http://www.astrometrica.at

Bailer-Jones C.A.L. , Rybizki J., Fouesneau M. et.al: 2018, AJ, 156, 58.

Bodryagin D. , Maigurova, N. :2015, OAP, 28, 163.

Bodryagin, D. V.; Bondarchuk, L. Ye.; Maigurova, N. V.: 2016, JDSO, 320.

Bodragin D. V., Bondarchuk, L. Ye.;Maigurova, N. V.: 2017, Sci. innov., 13(1), 46.

Gaia Collaboration: 2018, $A \& A, \mathbf{6 1 6}, \mathrm{A} 14$

Mason B. D., Wycoff G. L., Hartkopf W. I.: 2001, $A J$, 122, 3466.

Mason B.D. et al: 2001, Astron. J., 122, 3466.

REDUC software, [online]. Available at: http://www.astrosurf.com/hfosaf/reduc

Shulga O.V., Kozyryev Ye.S., Sybiryakova Ye.S. et al.: 2012, Space science and technology (KNiT), 18(4), 52 [in Russian]

Taylor M.B.:2005, ASPC, 347, 29.

Tokovinin A.: 2014, AJ, 147, 87.

Zacharias, N., Finch, C. T., Girard, T. M. et al.: 2013, AJ, 145, 44. 